\title{
LOS CRISTALES DE LA MEMORIA: VOCES Y MIRADAS FRENTE A LA HISTORIA ARGENTINA
}

\author{
POR \\ ANA ForCINITO \\ University of Minnesota, Twin Cities
}

En el marco de los festejos del bicentenario en Argentina (los doscientos años del 25 de Mayo de 1810, primera instancia de la emancipación nacional) la Secretaría de Cultura de la Nación junto con la Universidad Nacional de Tres de Febrero elabora un proyecto colectivo convocando a veinticinco cineastas a hacer un corto de ocho minutos cada uno. Así surge 25 miradas-200 minutos: cortos del Bicientenario. Desde documentales ficcionalizados ("Mercedes" de Marcos Carnevale y "Fallas de origen" de Juan Taratutto) hasta propuestas que narran la repetición de la misma secuencia narrativa ("Una vez más" de Gustavo Taretto), pasando por coreografías que ponen en escena una leyenda asociada a la patria ("Leyenda del Ceibo" de Paula de Luque), por reescrituras críticas de textos asociados al proyecto liberal decimonónico representado por Domingo Faustino Sarmiento ("NuevaArgirópolis" de Lucrecia Martel), por elénfasis en la historia de las imágenes del cine ("Gente querible" de Leonardo Favio, "Restos" de Albertina Carri y "Más adelante" de Lucía y Esteban Puenzo), por entrevistas ("Argentina del Bicentenario: las voces y los silencios", de Carlos Sorín), o por relecturas de batallas de la historia nacional ("Pavón", "El héroe que nadie quiso") o de personajes históricos ("El espía" de Juan Stagnaro), el resultado es una constelación de fragmentos que apuntan más que al formato documental ligado al relato histórico a repensar la relación de la imagen-sonido con el entramado de la memoria. ${ }^{1}$

\footnotetext{
Los veinticinco cortos, en orden alfabético, son: "El héroe al que nadie quiso" (Adrián Caetano), "Mercedes" (Marcos Carnevale), "Restos" (Albertina Carri), "Leyenda del ceibo" (Paula de Luque), "Guillermina P." (Inés de Oliveira Cézar), "La voz" (Sabrina Farji), "Gente querible" (Leonardo Favio), "Hija del sol" (Pablo Fendrik), "Posadas" (Sandra Gugliotta), "Malasangre" (Paula Hernández), "Intolerancia" (Juan José Jusid), "Ser útil hoy" (Víctor Laplace), "El abuelo" (Alberto Lecchi), "Nueva Argirópolis" (Lucrecia Martel), "En la trinchera" (Mausi Martínez), "Chasqui" (Néstor Montalbano), "Pavón" (Celina Murga), "(mi) Historia Argentina" (Gustavo Postiglione), "Más adelante" (Lucía y Esteban Puenzo), "Argentina del Bicentenario: las voces y los silencios" (Carlos Sorín), "El espía" (Juan Stagnaro), "Fallas de origen" (Juan Taratuto), "Una vez más" (Gustavo Taretto), "Nómade" (Pablo Trapero) y "Para todos los hombres y mujeres de buena voluntad" (Ricardo Wullicher).
} 
25 miradas tiene como punto de partida una convocatoria que invita a revisar la relación entre la imagen y la historia, en la medida en que sirve como conmemoración de un evento histórico fundacional. Sin embargo, incluso en los cortos en los que esa relación con la historia está más claramente expuesta, se establece una relación con el pasado asociada a los procesos de memoria que habitan la vida cultural argentina en las últimas tres décadas. Y en este trabajo de memoria que caracteriza las miradas del filme, se pone en relieve, en muchos casos, la presencia de la violencia en el escenario de la resignificación de la historia nacional (a través de anclajes en hechos traumáticos como determinadores de los doscientos años) para poner en cuestión no sólo la problemática relación entre historia y ficción sino además para dar cuenta de las diferentes capas de significación representadas en la recuperación estética que se hace de ese pasado.

En estas páginas me interesa acercarme a aquellos cortos que enfocan la representación de los doscientos años a través de la relación de la imagen con la violencia y que proponen un quiebre con la relación de la imagen con la evidencia de los eventos históricos (y por lo tanto producen un alejamiento del formato documental) para registrar, a través del registro visual y acústico una trasmutación de tiempos y espacios que apuntan al retorno (y a lo tardío) y a la simultaneidad. Esta transmutación implica repensar la relación mirada-pasado a partir del énfasis en la memoria como contrapartida de la rígida línea divisoria que traza la historia entre el presente y los eventos del pasado, y por lo tanto una propuesta de coexistencia del pasado en el presente. ${ }^{2}$

Muchos de los cortos nos ofrecen una serie de planos y de secuencias donde se pone en escena el tiempo y donde se reflexiona acerca de la temporalidad, tanto como representación de lo tardío en tanto manifestación del trauma como de la des-representación de la temporalidad lineal, donde la relación del pasado y el presente puede entenderse a través del concepto de imagen-tiempo de Gilles Deleuze, como una imagen que viene a problematizar la relación con la temporalidad cronológica. Con esto quiero decir que el peso que tienen los trabajos de memoria en la posdictadura argentina implican al mismo tiempo una recuperación histórica y una puesta en crisis del relato historiográfico

2 En su acercamiento a la memoria Maurice Halbwachs proponía una distinción entre memoria e historia que vale la pena mencionar. Halbwachs destaca el intento de la historia de generar y mantener una distancia con el pasado. Hay barreras infranqueables, y son los historiadores, como grupo selecto de especialistas, los que dedican muchos tiempo a leerlas y entenderlas. Se trata de un grupo pequeño que contrasta con el grupo social más vasto que recuerda el pasado (colectivamente) lo que tiene significación en el presente y por lo tanto hay una fuerte presencia de ese pasado que borra la distancia (y la barrera que necesita la historia). Al mismo tiempo, al pensar la temporalidad a través de Bergson en Matter and Memory (y luego Deleuze en La imagen-tiempo) el énfasis en la duración nos hace pensar el pasado al mismo tiempo como pasado y como presente. Y es esto último lo que muchos de los cortos del bicentenario parecen proponer: no una vuelta al pasado sino una vuelta al pasado que se vuelve presente (a veces como déjà-vu, a veces como lo tardío). Hay en muchos de los cortos un énfasis en los doscientos años, en su duración, en su ser pasado y al mismo tiempo presente.

Revista Iberoamericana,

Vol. LXXXI,

$\mathrm{N}$ úm.

251

Abril-Junio

$2015, \quad 409-433$ 
a partir de la representación del tiempo. La imagen en movimiento es aquí un espacio privilegiado para analizar esta relación y sobre todo en una serie de cortos que tienen que ver con la celebración de doscientos años de historia nacional condensada en ocho minutos. El retorno al pasado no se hace a través del flashback (la imagen ubicada claramente en el pasado que se rememora desde el presente) sino a través de imágenes que zigzaguean en el tiempo: son pasado y presente a la vez. ${ }^{3}$

Las respuestas a la convocatoria, heterogéneas en cuanto a las miradas que proponen, exponen una reflexión sobre la relación del cine con la historia, precisamente, como reinterpretación; incluso, podría afirmarse, en muchos casos, como ficción. Probablemente el corto que más explícitamente expresa el recorrido por la historia a partir de la imagen cinematográfica es el de Leonardo Favio en "Gente querible", donde entrama imágenes de sus propios filmes (Crónica de un niño solo, Juan Moreira, Nazareno Cruz y el lobo, Sinfonía y Gatica) a través de un voice over que acompaña (a veces superpone) los diálogos de los personajes con lecturas de citas de personajes históricos: José de San Martín, Manuel Dorrego, Juan Domingo Perón, Manuel Belgrano, Eva Perón, Mariano Moreno. Tanto la entrada como el cierre (que cita a San Martín y a Mariano Moreno respectivamente) dan cuenta de la relación entre la imagen y la narración, dando la clave al comienzo, con la voz de Favio, del homenaje que se rinde al primero de estos personajes "queribles" (anticipando en texto un "Dijo José de San Martín” y luego en su voz "Compañeros, juremos no dejar las armas de la mano hasta ver al país enteramente libre o morir con ellas como hombres de coraje" superpuesta a imágenes de su Crónica de un niño solo), para luego incorporar al final una doble voz: la de Mariano Moreno en la voz de Favio (sobre la ética de los dirigentes) y el grito de

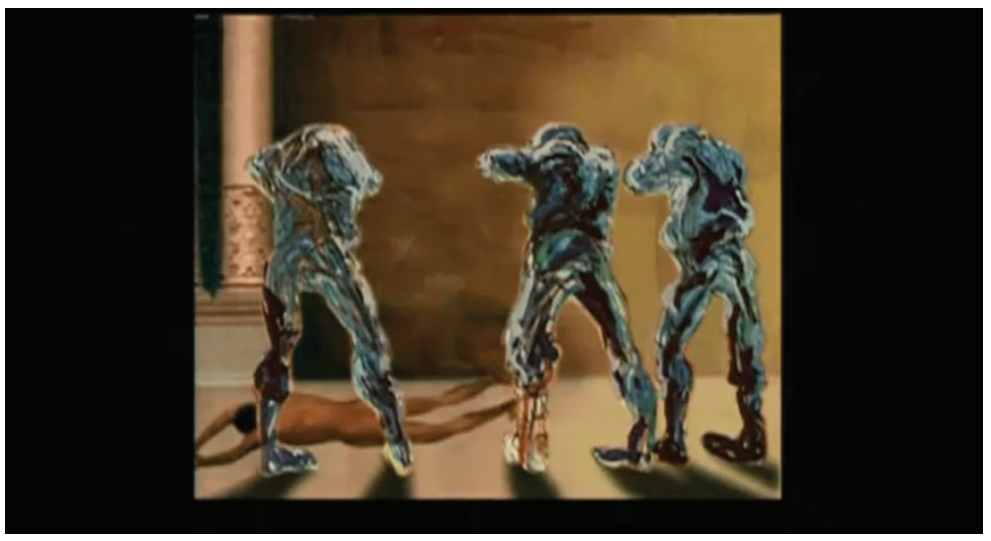

3 Y aquí entra en juego la imagen real y la imagen virtual a la que se refiere Henri Bergson en su trabajo sobre la memoria y que retoma Gilles Deleuze .Ver Deleuze 79-83.

Revista Iberoamericana, Vol. LXXXI, Núm. $251, \quad$ Abril-Junio $2015, \quad 409-433$
ISSN 2154-4794 (Electrónico) 


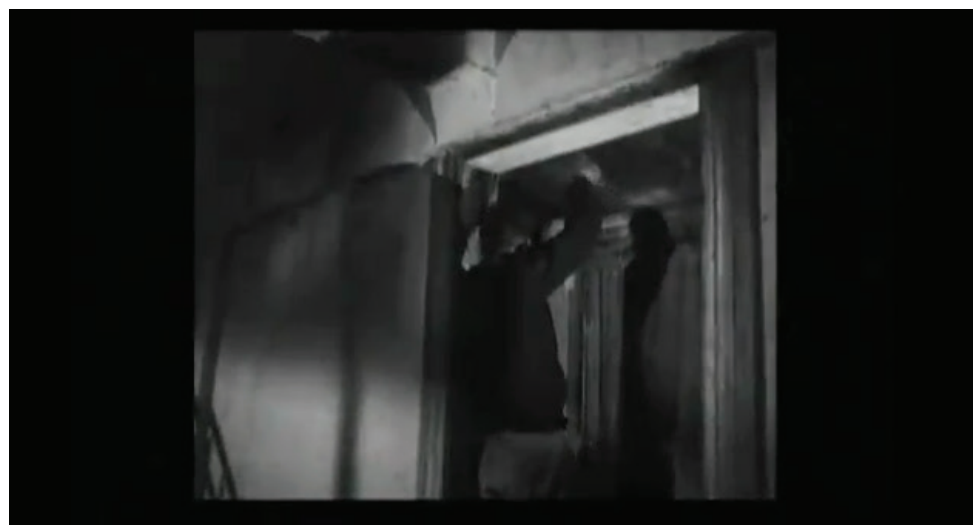

"Viva Perón" del personaje central de Gatica. La pregunta que parece resonar, no sólo estética sino además política, apunta a la posibilidad misma de una celebración de los doscientos años desde cualquier reclamo de objetividad para repensar, en cambio, los ecos de las citas de estos conocidos héroes y personajes históricos dentro del presente. La parte central del corto muestra imágenes de la Plaza de Mayo con Eva Perón para pasar luego al golpe de Estado de 1955 y a los fusilamientos de 1956. Casi como un encuadre de la parte central, "Gente querible" trabaja con la relación de la imagen y la voz, para corporalizar por única vez a uno de los personajes representados, Eva Perón, a través de su propia voz e imagen en la Plaza de Mayo, produciendo, en una de las pocas sincronizaciones voz-imagen del corto, un espacio centralizado en la plaza que contrasta con la desincronización imagen-sonido del resto del corto. Esta desincronización no sólo es espacial sino también temporal: el pasado histórico es simultáneo al pasaje por las películas de Favio y a un espacio que remite a las películas, a la Argentina del siglo XIX y XX, a los diferentes lugares de las masacres de 1956 y al espacio mismo del espectador que reconoce la voz de Favio como voice over trascendente, remitiendo a citas, y por lo tanto, a las voces con que se registra la trascendencia histórica dentro del corto, lo que el espectador ve asociado a imágenes de sus filmes y a animaciones con dibujos. Es justamente el cruce entre la memoria y la historia lo que sugiere la imagen en movimiento y la voz como significantes de la condensación del tiempo y el espacio, en tanto la historia se entrama en el presente, a través de sus obsesiones y de sus marcos, pero es al mismo tiempo pasado, transformable sólo a partir de nuevas interpretaciones, además un tiempo pasado que se da a conocer como imagen acústica: las voces y las citas a través de las cuales se recorren doscientos años. 
RETORNOS, CRISTALES Y RESTOS

En Writing History, Writing Trauma, Dominick LaCapra se posiciona distante de dos líneas bien demarcadas en el relato historiográfico: el modelo de investigación documentada y el modelo de investigación constructivista. LaCapra sostiene que la pregunta por el trauma “¿qué pasó?” termina siendo la pregunta por cómo se representa ese trauma. Lo que está en juego en el segundo modelo es el aporte de Hayden White en el cuestionamiento de la supuesta objetividad de la historiografía para verla desde sus intersecciones con el discurso literario, en oposición a esa supuesta objetividad. El eje, en el caso de LaCapra, es el trauma histórico y la posibilidad misma de su representación. LaCapra considera problemático el modelo que enfatiza la ficcionalización (y donde, en definitiva, el planteo es estético). Sin embargo las pretensiones de verdad de la historiografía, sostiene LaCapra, tampoco son convincentes en la construcción de sentido puesto que pueden ayudar a aceptar el pasado (come to terms es la expresión que usa en inglés), pero a través de reclamos de verdad "objetivadores". LaCapra enfatiza la necesidad de involucrar el afecto y la empatía, para exponernos a un efecto de "no resolución" (unsettlement), y por lo tanto a una inestabilidad. Los cortos, que ponen en escena la desaparición forzada a través de una construcción de sentido que pasa por lo estético y no por el reclamo de verdad (aunque tampoco tan alejados de ese reclamo, puesto que se lo hace desde otro ángulo) plantean esa "no resolución" como núcleo mismo de la desaparición y de la supervivencia. Pero esa "no resolución" tiene que ver no sólo con el evento en sí sino además con la imposibilidad de representarlo adecuadamente desde una narrativa y no sólo desde una narrativa objetiva sino además desde una narrativa marcada por la temporalidad lineal.

Siguiendo esta teorización, en esta parte voy a discutir la representación que tres directoras (Sandra Gugliotta, Paula de Luque y Albertina Carri) hacen de la imagen de la desaparición forzada en "Posadas", "Leyenda del ceibo" y "Restos", para discutir tres modalidades de representación de una temporalidad que se distancia de la narrativa lineal a través del retorno de lo tardío (la escena de desaparición presenciada por una hija o por testigos) en Gugliotta, el intervalo a través del cual los personajes de la narración del pasado habitan el presente y viceversa, enfatizando así las grietas de la temporalidad en de Luque y la representación de la imagen desligada de la temporalidad lineal para enfatizar el tiempo como devenir en Albertina Carri. ${ }^{4}$

En "Posadas" Sandra Gugliotta vuelve a la Argentina de diciembre 1978, durante la última dictadura militar. El corto narra la desaparición de una mujer que intenta huir junto con su pequeña hija. La escena del secuestro muestra también el destino de la niña

4 También "Malasangre" de Paula Hernández se centra en la violencia a través de una imagen (la acción de limpiar sangre) que recorre diferentes espacios y tiempos.

Revista Iberoamericana, Vol. LXXXI, Núm. 251, Abril-Junio 2015, 409-433 ISSN 0034-9631 (Impreso)

ISSN 2154-4794 (Electrónico) 

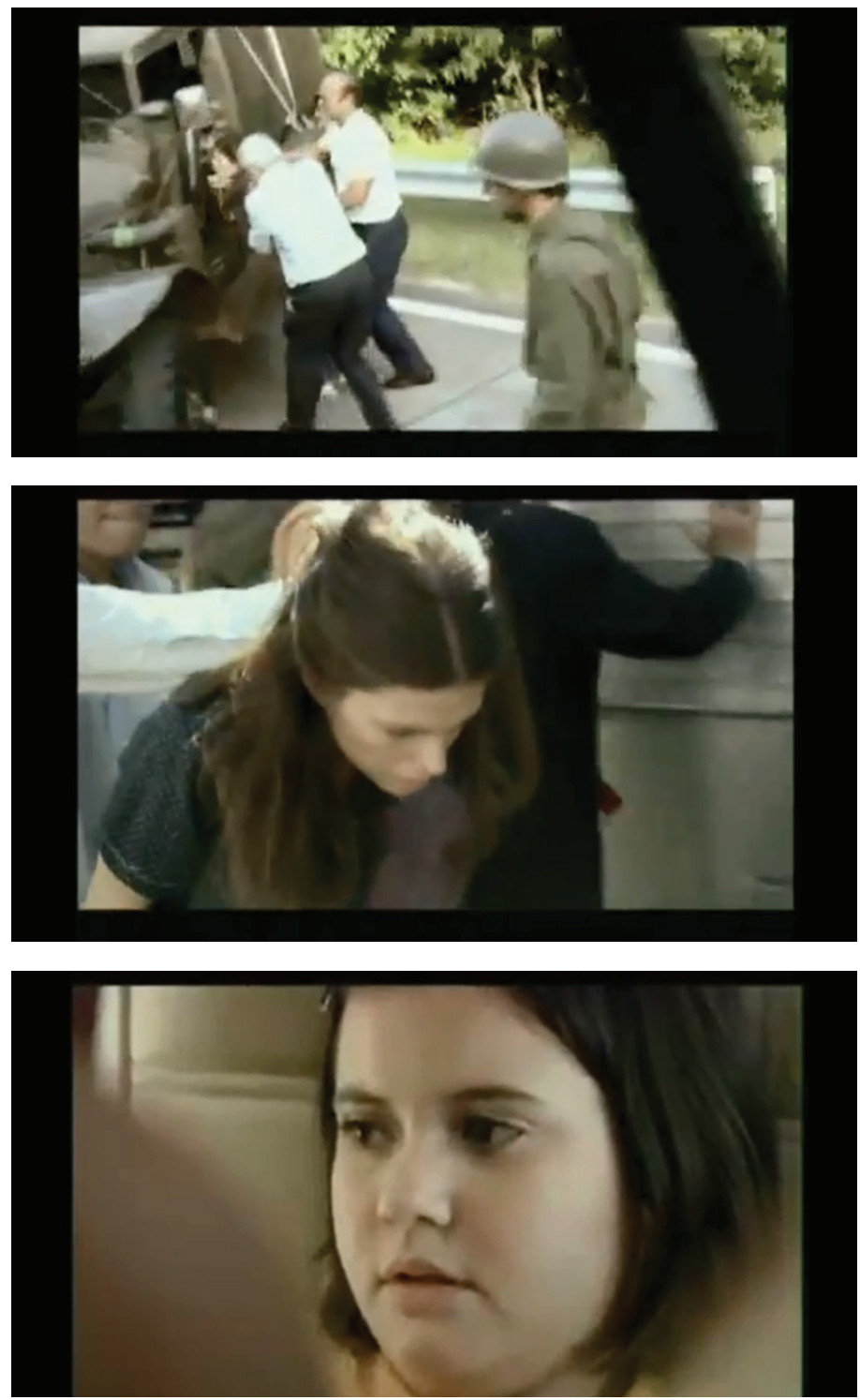

a quien otra madre se lleva para continuar el viaje en autobús. La representación de la desaparición forzada de personas implica un retorno a imágenes que reflexionan sobre el trauma y sobre la relación que establece la imagen con la historia, en especial cuando

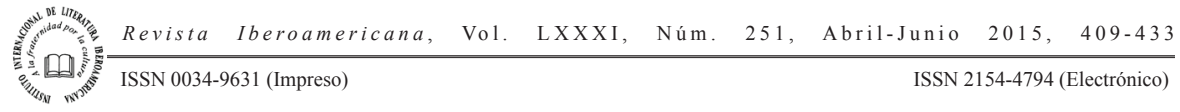


se enfatiza la desaparición como núcleo traumático ineludible que remite nuevamente a los trabajos de memoria más que a la rigurosidad del relato historiográfico.

En el corto de Guggliota no sólo hay un intento de representar la desaparición forzada de una mujer en la última dictadura militar, sino además de proponer esa imagen como condensación metafórica del bicentenario (una mujer a punto de desaparecer, una hija a punto de comenzar una vida incierta ¿apropiada? ¿retornada a su familia?) para plantear un quiebre que, volviendo a la relación trauma-historia, se aleja de la representación histórica para usar imágenes que muestran la historia reciente desde la pérdida y se enfocan más en el trabajo de la memoria (con lo que ella tenga de ficcional, o al menos de no rigurosamente registrada en archivos) que en el reclamo histórico. "Nos habían invitado a reflexionar sobre doscientos años de historia y yo tenía mucho deseo de hablar de la construcción de nuestro país a través de la violencia”, dice Gugliotta (Ranzani). El corto retorna a la escena del secuestro, a partir de imágenes que avanzan en una narrativa lineal (la madre se prepara para escapar con su hija, se van en un autobús, irrumpen los militares, hacen descender a los pasajeros y se llevan a la madre). Al mismo tiempo, la toma final nos muestra a su hija mirar por la ventanilla del autobús a su propia madre que ingresa en un automóvil militar para poner de relieve la relación de la mirada en el registro de la violencia. Es ese escenario de lo tardío, de lo que retorna a la imagen, a la construcción de sentido, al ejercicio del recuerdo, el que retoma Guggliota en su corto. En este caso sin embargo, las imágenes se reacomodan linealmente y, si bien mirar las imágenes de esta forma remite al recuerdo de la secuencia narrativa de la desaparición, el momento del secuestro mismo reviste una confusión de tiempos: gritos, nombres, respuestas, movimientos bruscos, marcados con planos de manos y piernas que concluyen en el secuestro de la protagonista frente a la mirada de su hija.

Uno de los puntos centrales de la discusión que plantea Cathy Caruth al repensar la relación del trauma y la narración es que si la narración implica la pérdida del evento (irrepresentable), el lenguaje poético sería capaz de dar cuenta de la irrepresentabilidad, de las fisuras, de los saltos temporales y de las ausencias. De un modo análogo, el lenguaje cinematográfico puede producir ciertos cortes en la temporalidad narrativa para detener la narración y condensar un determinado segmento, en este caso el del secuestro. El gesto narrativo se retiene como gesto, pero como interrupción de una narrativa lineal marcada por el énfasis en las partes del cuerpo que se mueven velozmente y son acompañados de voces que aunque restituyen la relación de lo que está fuera del marco visual y el espacio diegético de la narración, también contribuyen a enfatizar la confusión y la dificultad de restituir la linealidad temporal a esos escasos segundos de represión. Luego, el primer plano en la hija, ya dentro del autobús, al ver que se llevan a su madre por la ventanilla, vuelve a detener la narrativa lineal para convocarnos a repensar la relación de la mirada y el evento.

De otra forma y, haciendo alusión a otra persecución, Paula de Luque retoma en "Leyenda del Ceibo" una conocida narración nacional. Se trata de la captura de una

Revista Iberoamericana, Vol. LXXXI, Núm. 251, Abril-Junio 2015, 409-433 ISSN 0034-9631 (Impreso)

ISSN 2154-4794 (Electrónico) 


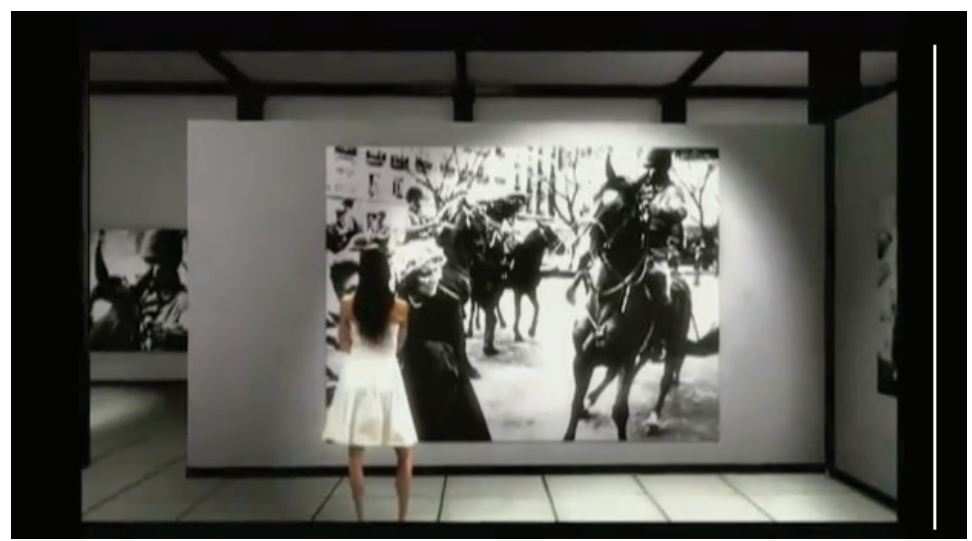

mujer indígena por parte de un español y de su muerte, quemada en la hoguera. Según la leyenda, hay una supervivencia, que tiene que ver con la transformación de Anahí (una mujer indígena) en ceibo, la emblemática flor nacional. Se trata en este caso de un doble emblema y un doble desplazamiento: en primer lugar de las mujeres de los pueblos originarios, y de la fundación de la patria sobre la violencia ejercida contra ellas.

La imagen fotográfica que abre el corto ("Marcha por la vida", Eduardo Longoni) y que se retoma al final se disuelve en un fundido, que tiene como punto de partida un primer plano de uno de los caballos desde los cuales los militares reprimen a un grupo de las Madres de Plaza de Mayo. Por lo tanto, la entrada que propone el filme nos ubica en el espacio de la última dictadura militar, pero además del registro que la imagen fotográfica hace de ese evento represivo. Por ello puede pensarse que uno de los puntos de partida es el registro documental de la imagen, que ahora es mostrado parcialmente por la cámara para deformarlo, por una parte, con un close-up que se acerca tanto al cuerpo del caballo que termina con la pantalla en negro y, por otra, para remitir al espectador a su propia in/capacidad de ver al intentar acercarse, casi tocar la pantalla a través de la cual se acerca al caballo. ${ }^{5}$ En contraste con el primer plano, vemos la imagen de un laberinto del cual la cámara se aleja para luego acercarse y dar comienzo a una secuencia (animada) de persecución en la cual la cámara toma (durante gran parte de la secuencia) la perspectiva de la perseguida que corre sin encontrar la salida, y jadea trabajosamente. Vemos luego sus zapatos blancos que corren, se detienen y siguen corriendo. La persecución es seguida por una danza que narra la lucha en la que

5 Remito a Mary Ann Doane ("The Close-up...") cuando reformula la pregunta por la relación entre el primer plano y las coordenadas espacio temporales, ya sea como recorte (Epstein) o como abstracción (Deleuze), siempre enfatizando lo que el primero tiene de no articulable y suplemental como punto de partida para pensar su dualidad (la magnitud y el detalle, lo minúsculo y lo gigante, de proximidad ,de frontera de lo visible/inteligible, y de lugar de colapso entre el detalle y la totalidad).

\footnotetext{
Revista Iberoamericana, Vol. LXXXI, Núm. 251, Abril-Junio $2015,409-433$ 


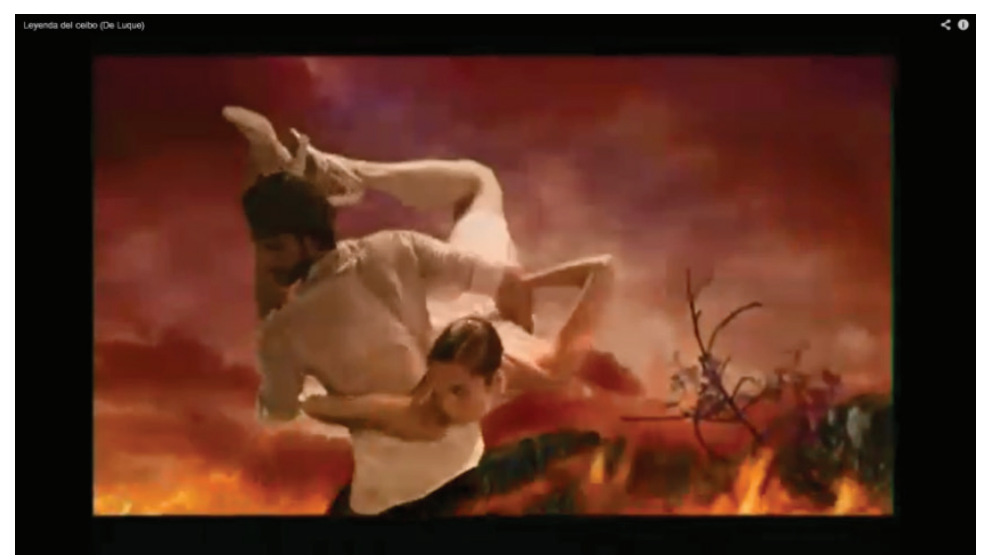

será vencida. La cámara registra la carrera desde diversos ángulos y corta la cabeza de esta mujer vestida de blanco perseguida por un hombre hasta el borde de un precipicio. Blancos son incluso esos zapatos de tacones que ubican a la mujer perseguida en otro espacio y tiempo-histórico mucho más reciente, enfatizando asimismo la repetición de los traumas históricos registrados como la pugna entre opresores y oprimidos. Las imágenes se entrelazan en desplazamientos metonímicos: el laberinto deviene una huella digital, y desde esa huella se retorna a la fotografía del comienzo, para mostrarla por primera vez completa y además mostrarnos a la misma (y sin embargo otra ) mujer vestida de blanco mirar esa fotografía en una exposición.

El tiempo se entrecruza con tiempos más recientes: las imágenes zigzaguean entre algunas asociadas al pasado y a la leyenda (la hoguera por ejemplo) y al pasado reciente (los cuerpos que caen al río, las fotografías, la exposición fotográfica). La leyenda de Anahí, una mujer indígena, se reescribe como la historia de otras cautivas, otras persecuciones y otros asesinatos y desapariciones mucho más recientes. La danza y el forcejeo seguido de la caída violenta en cámara lenta primero y multiplicada en diferentes imágenes tanto en el comienzo de la caída como en el mar son interrumpidos por la continuación de la danza y la posterior muerte de la víctima en el fuego. La imagen del mar y de los cuerpos que caen (¿son arrojados?) al mar forma parte de la desaparición forzada durante la última dictadura militar. Sin embargo, vemos nuevamente a la víctima (o a quien la representaba, la mujer de blanco) frente a una exposición fotográfica, frente a "Marcha por la vida" de Longoni. Esta imagen cristaliza la fusión del pasado y del presente (y el devenir en términos de Deleuze asociado a la imagen-cristal). Su captor está también en el mismo espacio. La víctima, que ahora, mira primero la fotografía en blanco y negro y luego mira a la cámara y por lo tanto al espectador, está ahora sí ubicada en la historia, fuera de la leyenda. En un sentido se trata de la supervivencia de la cautiva que permite el giro ficcional del corto pero, por otra parte, de su traumática repetición.

\footnotetext{
Revista Iberoamericana, Vol. LXXXI, Núm. 251, Abril-Junio 2015, 409-433 
La mirada que ejercita el corto tiene como punto de partida una fotografía asociada a la represión de la última dictadura militar a través de la cual la cámara nos propone ver las imágenes recreadas de una leyenda asociada al pasado que ya condensaba la violencia y la resistencia. Como sugiere Ana Amado, en esa conflictiva relación entre historia y ficción el cine no puede distanciarse tanto de la "mostración" (34), aunque sí puede alejarse de la mostración de imágenes que narran sin condensar, quebrar o resquebrajar los contornos de la narración histórica. ${ }^{6} \mathrm{Y}$ es aquí el close-up el que marca la pausa en la narrativa lineal para dar inicio y fin a la historia encuadrada (la reinterpretación de Leyenda del Ceibo a través de una coreografía) y al mismo tiempo el que despierta, como nos recuerda Doane, en su estudio sobre el primer plano, la pregunta "¿qué pasa más allá de lo que puedo ver?" ("The Close-up" 96) . Hay una cercanía que hace a la imagen cercana e imperceptible a la vez (y esto es llevado al extremo porque se ingresa a la historia encuadrada a través de un primer plano que deviene pantalla en negro y se sale de esa historia a través de un laberinto que se transforma en una huella y luego en el mismo primer plano del comienzo para finalmente alejarse y mostrar a la protagonista mirando la fotografía). En esta sucesión de planos que permanentemente remiten a lo que está más allá del campo visual, el inconsciente óptico (el detalle que lleva a la historia encuadrada) sostiene la clave (o la huella) de esta condensación de los doscientos años de historia que propone De Luque. ${ }^{7}$ La escena final y el énfasis en la mirada sobre la violencia cierran la reinterpretación de la leyenda, su retorno al presente, a partir de imágenes que se suceden rompiendo la continuidad lógica y temporal y que afirman la irrupción del pasado en escenarios recientes de la historia y, al mismo tiempo, la interpretación del pasado reciente como clave de lectura de la historia. Se trata, en ambos casos, de un gesto de retorno a espacios que albergan lo recordado y lo olvidado, a la manera de la imagen de la habitación de la infancia usada por Walter Benjamin para hablar de la memoria y su relación con la imagen. La habitación de la infancia a la que Benjamin se refiere es un lugar repleto de detalles que rodean justamente lo que no se

6 Amado no se refiere a este filme sino que está hablando justamente de una operación inversa que es la de los filmes de los ochenta en la redemocratización para sostener lo siguiente: "Para una sociedad que con la ruptura de la oscuridad y el silencio quería saber, las ficciones cinematográficas coincidieron en añadir su cuota interpretativa, o simplemente informativa a la circulación de discursos sociales sobre los procedimientos genocidas y sus víctimas. Tras un período de no ver nada, las imágenes del cine podían permitir verlo todo" (34). Amado entonces compara la producción cinematográfica de los ochenta con la ficción literaria en vez de exponer la verdad intenta condensarla (34). En el 2010, el corto de de Luque encuadra esa condensación a través de la cámara y del retorno a la leyenda pero toma como punto de partida la imagen fotográfica que sirve para revelar la verdad.

7 Walter Benjamin dice refiriéndose a los primeros planos: "En una ampliación no sólo se trata de aclarar lo que de otra manera no se veía claro, sino que más bien aparecen en ella formaciones estructurales del todo nuevas. Y tampoco el retardador se limita a aportar temas conocidos del movimiento sino que en estos descubre otros enteramente desconocidos [...]" (62-63). También sugiere que es a través del primer plano y a través de la cámara que experimentamos el inconsciente óptico (La obra de arte 63). 
puede recordar porque ha quedado oculto. Un lugar del pasado así, reúne a través (o a pesar) de detalles minuciosos la historia de un olvido, o de un recuerdo incompleto que se reinterpreta tardíamente y que de alguna forma había quedado latente (o suspendido) como una imagen. El ejercicio del retorno en "Posadas" y en "Leyenda del Ceibo" puede leerse como la búsqueda de esa memoria perdida (la imagen del secuestro en la primera y leyenda del ceibo como huella o la imagen fotográfica en la segunda). Ese retorno a la escena de la desaparición es al mismo tiempo, una revisión y una demora: por una parte un ejercicio de re-ver, de volver a mirar, y por otra, la existencia de un silencio y de un saber tardío, demorado. ${ }^{8}$

La desaparición, el asesinato, la masacre como nudo traumático (que nos deja en el silencio) se recobra aquí como ausencia de voz. En "Leyenda del ceibo" se trata de un personaje mudo, sin voz, sin gritos. Se trata de un personaje que muere en silencio. Pura corporalidad sin voz con un mudismo sólo alterado en las imágenes de la carrera donde la escuchamos respirar agitadamente. En el caso de "Posadas" se escuchan las voces, gritos (preguntas, órdenes) de los militares que detienen el autobús, alguien que contesta a la pregunta "¿a dónde van? con un "A Posadas” y voces de militares que señalan a la protagonista mientras se la llevan y su hija mira en silencio mientras se escucha decir (las imágenes muestran varias manos rodeando a la joven militante) "no mirés, no mirés". Luego el silencio final. El punto de partida en ambos cortos es diferente en cuanto a lo acústico: el mutismo desde el inicio en "Leyenda" y la pérdida de la voz en "Posadas" en contacto con la represión militar (que representa "la" voz, en el sentido que le otorga Elaine Scarry). ${ }^{9}$

8 En la historia que recuenta Benjamin, debido a que su padre no le cuenta los detalles de esa muerte, él vuelve a ver en esas imágenes un saber demorado, al entender a través de los años que esa charla que recordaba en esa habitación escondía un silencio posteriormente recobrado. Dice Benjamin: "So the room I slept at the age of six would have been forgotten, had not my father come in one night - I was already in bed - with the news of a death. It was not really the news itself, that so affected me..." (Selected Writings 633), y luego cuenta nuevamente la historia con algunas diferencias: "I was perhaps five years old. One evening - I was already in bed, my father appeared, probably to say good nights. It was half against his will I thought, that he told me the news of a relative's death. The deceased was a cousin, a grown man who scarcely concerned me. But my father gave the news with details, took the opportunity to explain, in answer to my question, what a heart attack was and was communicative. I did not take in much of the explanation. But that evening I must have memorized my room and my bed, the way you observe with great precision a place where you feel dimly that you'll later have to search for something you've forgotten there. Many years afterward I discovered what it was. Here in this room, my father had 'forgotten' part of the news about the deceased: the illness was called syphilis" (635).

9 Me refiero aquí a la pérdida del mundo y de la voz del prisionero (Scarry lo ubica en el escenario de la tortura) y la presencia acústica de la voz y el mundo del torturador: "Although the torturer dominates the prisoner both in physical acts and verbal acts, ultimate domination requires that the prisoner's ground become increasingly physical and the torturer's increasingly verbal, that the prisoner become a colossal body with no voice and the torturer a colossal voice (a voice composed of two voices) with no body, that

Revista Iberoamericana, Vol. LXXXI, Núm. 251, Abril-Junio 2015, 409-433 ISSN 0034-9631 (Impreso)

ISSN 2154-4794 (Electrónico) 
La imagen del retorno a la habitación de la infancia de Benjamin, y a los detalles que rodean y merodean la búsqueda de un recuerdo que se escapa, tiene que ver con la memoria como una práctica visual, en el sentido en que son esas imágenes del pasado las que adquieren nuevos sentidos en el presente. Estas metáforas no son sólo espaciales sino además temporales puesto que implican un proceso de actualización (el sentido que se le da al recuerdo).

Probablemente el corto que más elabora la relación de la imagen con el residuo y la mirada es "Restos”, de Albertina Carri. "Acumular imágenes ¿es resistir? ¿Es posible devolverles ahora el gesto desafiante?" Estas son las preguntas que la voz de la misma Carri formula (el voice over del documental) mientras vemos a un hombre desnudo agazapado en un bosque. Sin embargo, el voice over no remite en Carri a la afirmación del documental (o lo documental) sino en todo caso de sus restos. A continuación, la imagen muestra el fuego quemando celuloide. Vemos las cintas retorcerse, desintegrarse. Luego, cintas acumuladas unas sobre otras, en pilas. La voz de Carri habla del cine de los sesenta y setenta como arma política, de películas filmadas en la clandestinidad, del desafío del cine frente a la represión. Un hombre joven proyecta una filmación. Vemos las luces de la ciudad en la noche traspasarse a las imágenes de quien comienza a correr. Mientras la voz de Carri habla de la represión cultural, un hombre desnudo corre ("eliminadas como los rastros de los perseguidos", "quemadas por quienes las habían creado"). Una mancha violeta comienza a cubrir la imagen y se expande hasta casi cubrir el primer plano de quien huía. Nuevamente el close-up para detener la narrativa, repensar la mirada y condensar el sentido: una imagen que se quema desde el centro hacia los bordes.

Ya no vemos. "Desaparecidas ellas también" dice la voz narrativa antes del fundido en negro. "No es ficción ni tampoco documental: es un ensayo", dice la misma Carri de su corto (Ranzani). En su ya clásico estudio acerca del espejo acústico, Kaja Silverman sostiene que en las representaciones no feministas el hombre es quien ocupa el espacio de sujeto de habla (y eso se hace evidente en los documentales donde el voice over es generalmente una voz masculina) y que las mujeres están siempre asociadas a su imagen corporal. A través de esta sincronización, se limita la mujer a su cuerpo (y con ello a su representación como imagen) y se deja a los varones la posibilidad de representar lo incorpóreo, la trascendencia y el saber. Carri produce un cambio en este esquema. La voz trascendente es la suya propia en un voice over. El cuerpo representado, masculino y vulnerable, simultáneamente, corre escapando de la violencia narrada.

Cintas de filmación sumergidas en el agua ponen en escena la referencia al destino de las imágenes en la última dictadura militar. Las vemos desintegrarse. El corto

eventually the prisoner experience himself exclusively in terms of sentence and the torturer exclusively in terms of self-extension" (57-58).

Revista Iberoamericana, Vol. LXXXI, Núm. 251, Abril-Junio 2015, 409-433 ISSN 0034-9631 (Impreso) 

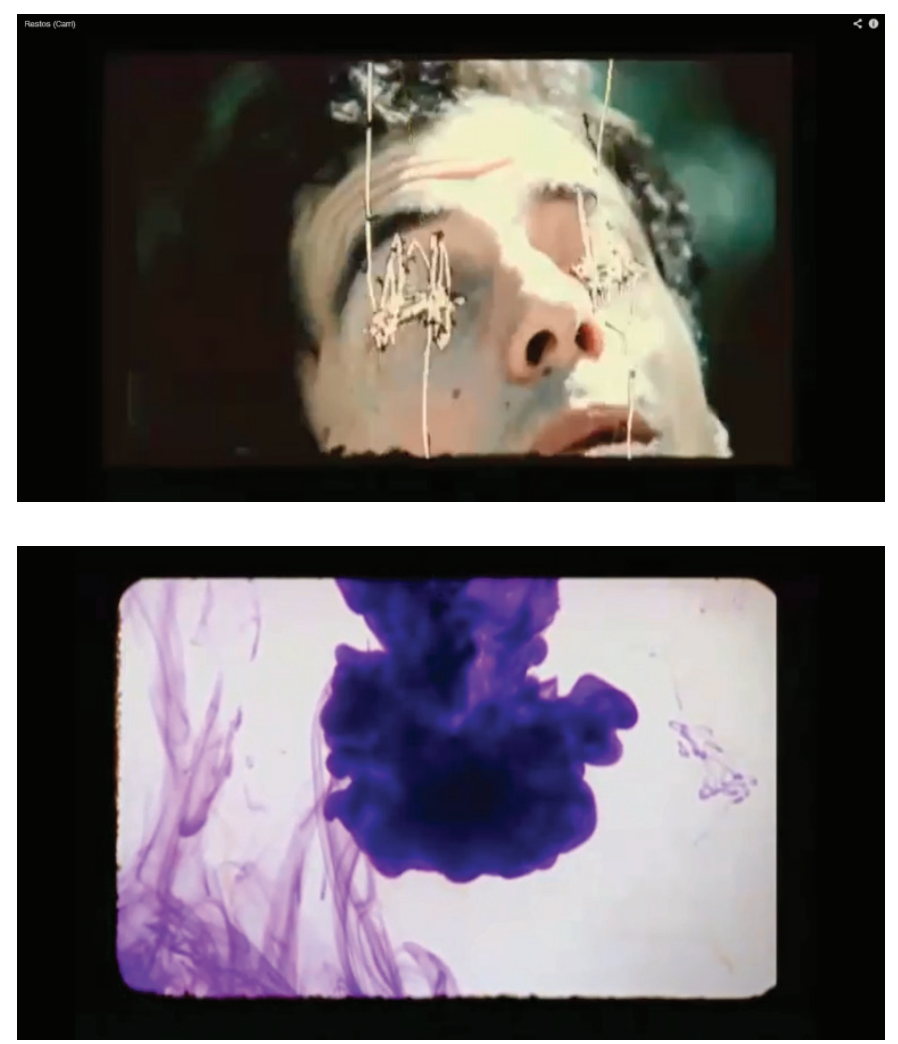

indaga en imágenes y palabras por el destino de las cintas, algunas destruidas, otras que sobreviven y recuperan su firma de autor. Pero además indaga sobre el destino de la mirada: ahora el personaje masculino, cámara en mano, filma. Primero se afirma la mirada de la víctima. Luego el close-up en sus ojos (como la marca del terror frente a lo visto) da lugar a un cuestionamiento de la mirada. Sus ojos comienzan a borronearse con raspaduras, ya casi no pueden verse. La voz de Carri enfatiza la pérdida del sujeto colectivo: "Desde esta orfandad que sólo puede decir yo me dejo encandilar por las imágenes perdidas. Buscarlas es resistir a esta intemperie sin sueños”. Se retorna a la memoria a través de imágenes perdidas.

Las imágenes implican una recuperación de lo no narrado y así se entrelazan, como sugiere Caruth, con esas modulaciones que se pierden en la recuperación del relato histórico. La condensación que rige el corto permite jugar con imágenes y planos de modo tal que la interrupción del hilo narrativo sirve para señalar con el primer plano $\mathrm{y}$ el voice over lo que queda invisible, o lo que queda fuera y de lo que trasciende

Revista Iberoamericana, Vol. LXXXI, Núm. $251, \quad$ Abril-Junio $2015, \quad 409-433$
ISSN 2154-4794 (Electrónico) 
en forma de close-up o en forma de sonido, de-sincronizado del cuerpo, como voice over, aunque podamos reconocer la subjetividad de Carri, que se propone como la voz trascendente (¿sobreviviente?) del terror del pasado. Los restos son también las manchas rojas, violetas, azules, que van cayendo y dispersándose en el agua. Son los restos, tal vez, de la memoria y sobre todo, de sus imágenes, ahora fragmentos de cintas que también caen lentamente. "Restos" apunta a recuperar el sentido de lo metafórico, de lo poético, de la fisura irrepresentable que sustenta el punto nodal del trauma, la violencia y la imagen visual.

Hay un intento de recorrer las huellas borroneadas, mirar atrás una historia cultural y artística, a través de un gesto que se condensa en la pérdida, en la desaparición forzada: la borradura frente a la huella y el lugar del cine en la trama de las imágenes, sonidos y sentidos de esta propuesta de revisión histórica.

\section{LO INVISIBLE Y LO INAUDIBLE}

El registro acústico puede también servir para dar cuenta de las presencias invisibles o invisibilizadas y al mismo tiempo, como sugiere Silverman, para marcar otro régimen de vigilancia. Ese es el caso de Lucrecia Martel, en "Nueva Argirópolis" donde retorna a la escritura de Domingo Faustino Sarmiento para poner en escena la relación voz-escritura, no sólo en el pasado, sino en una yuxtaposición pasado-presente que condensa espacios y tiempos, a la manera de la imagen cristal de Deleuze aunque no completamente porque se trata de una nueva Argirópolis, y por lo tanto el tiempo pasado y presente no están fundidos en el título, sino diferenciados. El corto usa una serie de fragmentos que apuntan a una problemática relación entre la imagen y la rigurosidad lineal histórica para dar cuenta de rupturas que se marcan, como en todos los filmes de Martel, a través del sonido. Martel propone una mirada sobre la historia a partir del diálogo entre pasado y presente, memoria e historia, escritura e imagen acústica, voz articulada y susurro e invisibilidad y visibilidad. El texto de Sarmiento, anterior a la consolidación nacional, que se publica en Chile en 1850 con el título Argirópolis o la Capital de los Estados Confederados del Río de la Plata plantea para la pacificación del Río de la Plata (son los últimos años del gobierno de Juan Manuel de Rosas) la solución de convocar un congreso y crear la capital en la isla Martín García (en poder de Francia en ese momento). ${ }^{10}$ En una nota posterior a la realización del corto, Martel se refiere a esta isla como una fantasía y, al mismo tiempo, un emblema. En su re-visión las islas del Delta son la nueva propuesta, en vez de "una isla donde se pueda refundar una especie de nación" como en el caso de Sarmiento (Ranzani). El

10 También afirma la importancia de la libre navegación de los ríos para la "independencia, desarrollo y libertad del Paraguay, el Uruguay y las provincias argentinas del Litoral".

Revista Iberoamericana, Vol. LXXXI, Núm. 251, Abril-Junio 2015, 409-433 ISSN 0034-9631 (Impreso)

ISSN 2154-4794 (Electrónico) 


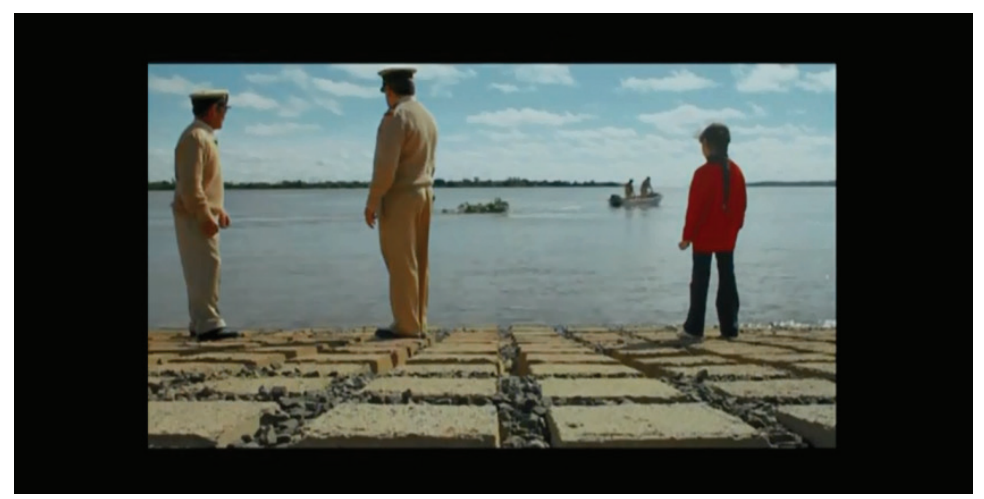

filme retorna al texto a través de la apropiación que se hace de Argirópolis desde los bordes (escuchamos decir "Argirópolis" a una mujer en lengua wichi, en un video que circula en internet). Asimismo, la superposición de tiempos nos permite retornar a las imágenes de Argirópolis de Sarmiento desde las imágenes planteadas por Martel en el presente: las comunidades indígenas siguen "bajo sospecha" de una mirada vigilante que las excluye del proyecto nacional. ${ }^{11}$

Sarmiento y su escritura fundacional de la patria liberal se refleja entonces en un juego de espejos a través de imágenes que van a colapsar las temporalidades, pero no para repetir el pasado en el presente, sino para sugerir sus resonancias, sus bifurcaciones y apropiaciones y para señalar, asimismo, las disonancias que se producen en la repetición. A la escritura que se retoma en el título del corto se contrapone una oralidad marcada no sólo por voces que los gendarmes intentan traducir al castellano sino además por voces en lengua wichi que se multiplican sin traducción en internet, como nueva forma de "escritura", sobre todo porque también está marcada por el carácter fundacional de la Nueva Argirópolis con referencias al himno nacional argentino.

La fragmentación del corto de Martel dificulta la representación transparente de la memoria para poner en cuestionamiento la lógica a la que se somete la imagen narrativa cuando ésta es sólo capaz de narrar la versión oficial de los hechos. Un grupo de cinco personas (sin documentos) de la comunidad wichi son detenidos por la prefectura, que presumiendo que transportan drogas por el Río Bermejo, los detiene para interrogarlos y someterlos a una radiografía que finalmente no logra dar evidencia de la sospecha

${ }^{11}$ La isla Martin García se trasforma más tarde en un espacio usado por la nación liberal de la llamada Conquista del Desierto (1879) para el confinamiento de cautivos y cautivas indígenas. Por lo tanto, Argirópolis (pese al énfasis de Sarmiento en la convocatoria a un congreso y una revisión de los tratados y pactos federales) representa tanto la presencia francesa en el imaginario nacional de la escritura de la patria (la isla Martín García estaba en manos de los franceses en el momento en que Sarmiento escribe el texto) como un espacio que será usado (veinte años después de la escritura del texto) para la reclusión de cautivos indígenas.

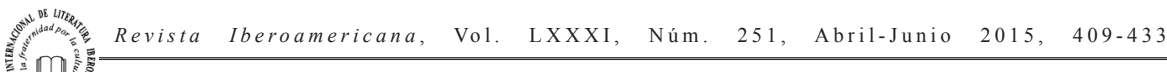
ISSN 0034-9631 (Impreso)

ISSN 2154-4794 (Electrónico) 


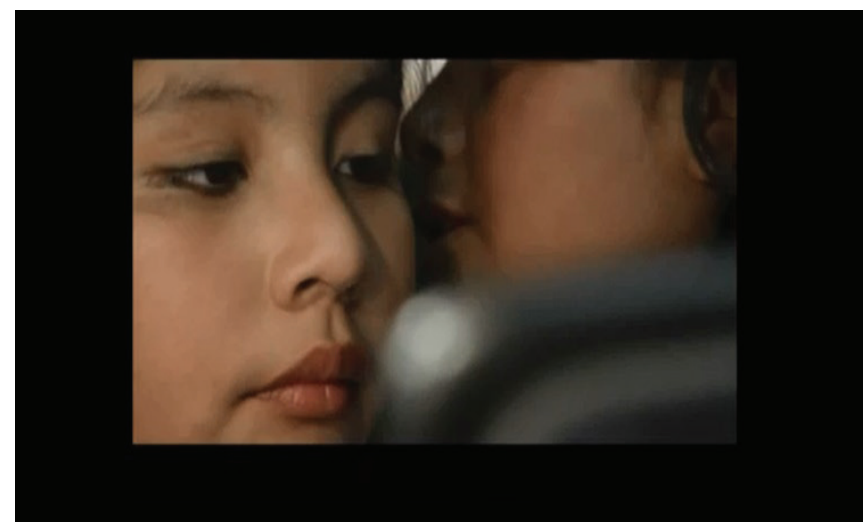

inicial. La mirada (en busca de la evidencia que daría la prueba a la presunción de la prefectura) es ejercida como vigilancia en un doble sentido: por una parte, con la mirada que los encuentra sospechosos (como extranjeros a la nación) y con la placa que examina el interior de sus cuerpos.

La disputa comienza a ponerse en escena a través de la superposición de voces, en castellano y wichi. La presencia visual de los “acusados" reside justamente en que se hacen visibles sólo como sospechosos. El corto enfatiza junto con los retazos de historia las voces que subvierten la relación imagen-sonido: los susurros al oído de una niña cuando traduce al castellano el video de internet ("indígenas e indigentes, somos invisibles"; "No tengan miedo de moverse. Somos invisibles"). Los susurros contrastan con la voz de los médicos que luego de mirar las radiografías dicen "no tienen nada" acerca de los detenidos. También contrastan con el "Se oyen voces" que los gendarmes dicen en el río. Esta "visibilidad" (se hacen visibles porque son escuchados, son escuchados porque son sospechosos) es cuestionada por el "Somos invisibles" para dar cuenta del conflicto entre una visión vigilante y la invisibilidad de los sujetos sociales que sólo son vistos

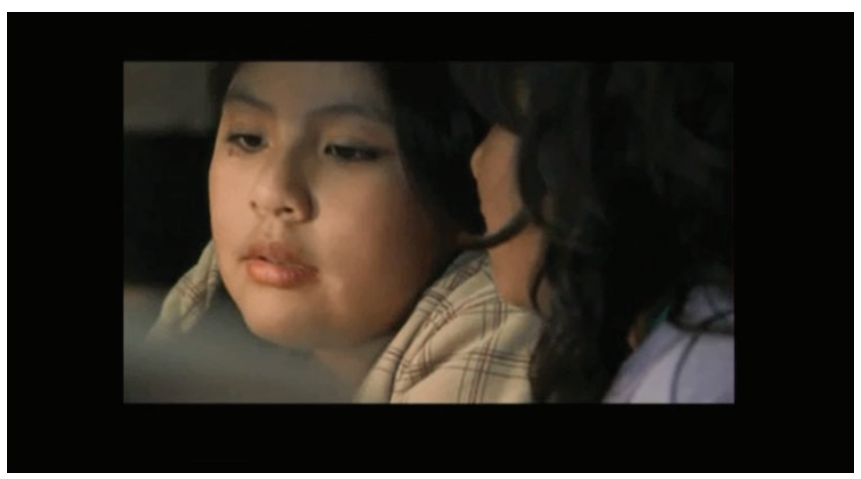

Revista Iberoamericana, Vol. LXXXI,
Núm. 
para ser acusados. ${ }^{12}$ Martel provoca un doble juego del encuadre, donde se evidencia una superposición de miradas: la de la cámara, que registra las incongruencias y la de la prefectura, que intenta comprobar la teoría del traslado de drogas y está en el proceso de "investigación" (una investigación que pasa tanto por el régimen vigilante de la mirada como del sonido). Ana Amado propone justamente el régimen vigilante de lo acústico, como "evidencia" de la presencia de esa otredad sospechosa, en la frase final del corto, dicha por la prefectura: "se escuchan voces"("No son como nosotros..."). Lo acústico juega aquí un rol importante porque frente a lo traducido tenemos también los pasajes no traducidos y los susurros. En ambos casos se quiebra el intento de restitución de sentido en la lógica vigilante de la nación como una Nueva Argirópolis, donde la referencia a este texto particular de Sarmiento no puede separarse de su rol como ideólogo de la nación liberal argentina y sus prácticas racistas y autoritarias que culminan con el genocidio de la llamada "Campaña del Desierto".

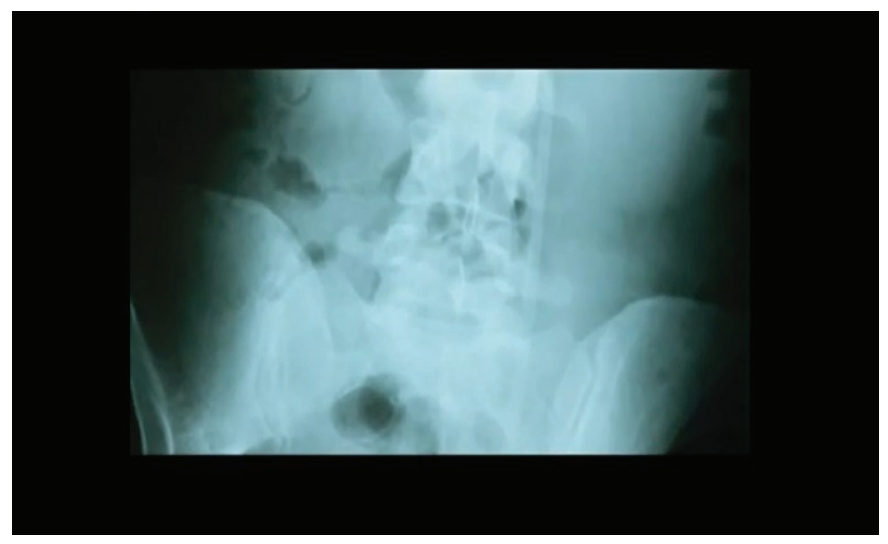

Respecto de la voz Silverman propone que si se la interpreta dentro del marco psicoanalítico y a través de su relación con la voz de la madre, se produce una reproducción del lenguaje patriarcal al quedar anclada la voz a la corporalidad. Al referirse al lenguaje materno, Silverman no se centra en las subversiones de lo pre-edípico, del cuerpo maternal o en instancias pre-lenguaje o de sus excedentes como en el caso del nuevo feminismo francés. Su acercamiento critica las versiones de Luce Irigaray y Julia Kristeva (la etapa pre-edípica, la etapa pre-lenguaje) porque sostiene que en ambas teóricas, la voz materna sigue anclada en la corporalidad. Para Silverman ese anclaje en

12 En su propuesta, Carlos Sorín representa la voz clara y articulada de un escritor (O’Donnel) y un historiador (Carlos Altamirano) frente a los silencios de los marginados (sólo en imágenes, sin voces ni sonidos).

ISevista Iberoamericana, Vol. LXXXI, Núm. 251, Abril-Junio $2015, \quad 409-433$
ISSN 2154-4794 (Electrónico) 
la corporalidad es una marca de la asociación de lo femenino al cuerpo y una negación de la trascendencia de la voz (y en Silverman la trascendencia de la voz es crucial en la subversión de lo femenino). El análisis de Ana Amado en "No son como nosotros...", sin embargo, da cuenta de la posibilidad que ofrece la entrada interpretativa a partir de la lengua materna y la violencia ejercida por la lengua paterna (el español, la ley de la nación decimónica liberal representada por Sarmiento) en la aniquilación de la diferencia, que sobrevive sólo en ese espacio no ya pre-edípico, sino en una situación pre-edípica que nunca fue doblegada totalmente y cuya reaparición dentro de la lengua paterna se da en intermitencias intraducibles. Esto habilita entonces la problemática relación no lineal, sino intermitente y simultánea, con la temporalidad. Si la traducción da cuenta de la imposición de la lengua paterna (que vigila los cuerpos y la modulación del sonido-sentido) lo intraducible remite doblemente a lo marginalizado y excluido (controlado justamente desde la lengua y el cuerpo) y a lo subversivo, lo no asimilable a la norma y por lo tanto doblemente huella de una exclusión y de una pertenencia extranjera a la norma que lo excluye. Martel lleva esta contraposición entre lenguajes a un primer plano que marca la importancia de lo que se susurra, de lo que se dice en voz alta: la niña que traduce al oído de otra niña el video que vemos y escuchamos mientras esta traducción tiene lugar. Por lo tanto, escuchamos la voz en lengua wichi (donde se dice Argentina y Nueva Argirópolis), la voz de la niña que repite en voz alta la traducción a las autoridades y el susurro débil hasta el momento del primer plano de la niña que traduce.

En el momento en que la cámara se acerca a la niña en el primer plano, la escuchamos decir "Indígenas e indigentes, no tengan miedo de moverse. Somos invisibles" (la otra niña no lo repite). Este primer plano hace visibles y presentes a las niñas para señalar, al mismo tiempo, una yuxtaposición de voces: la de la líder de la comunidad en lengua wichi (que vemos en la imagen del video que proyectan, pero también como voz en off en el primer plano de las niñas), la de la niña que repite la traducción en voz alta y la de la niña que traduce al oído de la otra en susurros en castellano. El primer plano enfatiza la visión y la posibilidad de ver en proximidad. En esa yuxtaposición del primer plano como primer plano del susurro puede entenderse otro tipo de trascendencia de la señalada por Silverman, en este caso anclada en la corporalidad donde se abstrae parte del rostro de la niña (la boca) que susurra al oído de otra niña (el rostro). Así se crea una complicidad con el espectador recortada de las coordenadas espacio temporales de la imagen: se la abstrae de su espacio para acercarla al espacio del espectador. Lo que retorna en la "Nueva Argirópolis" de Martel es la violencia en la construcción de otredad, en su vigilancia, en su traducción como marca de doscientos años de historia nacional. Son los susurros, como caracterizan gran parte del trabajo de Martel, los que dan la clave sobre las limitaciones de la mirada que registra una historia que no se puede restituir completamente y que hace visibles a los miembros de esta comunidad sólo a

Revista Iberoamericana, Vol. LXXXI, Núm. 251, Abril-Junio 2015, 409-433 
través de su carácter de sospechosos y de traducciones que son audibles hasta cierto punto (es decir, en tanto son traducidas a la lógica del castellano y a su dominancia) y que dentro del filme se escuchan a veces con dificultad y dan cuenta no de los silencios de la comunidad sino del silenciamiento al que la comunidad es sometida.

LAS VOCES, LAS MEMORIAS, LOS ESPACIOS Y LOS TIEMPOS

La relación entre la voz y el espacio puede hacernos repensar también los caminos de la memoria. Esto puede verse muy especialmente en "La voz", de Sabrina Farji donde el recorrido histórico se hace a través de planos medios (y dos primeros planos) de una mujer (la actriz Elena Roger) que canta y recita el himno nacional y que representa a diferentes mujeres que cuentan su historia para evidenciar que no puede representar "la voz" de la nación sino las voces que quiere incorporar por un lado (las mujeres que cuentan su historia) y las que irrumpen en su voz como involuntarias memorias de voces de otros. Farji usa la voz en off/voice over para habitar la misma corporalidad (una mujer que representa también a la nación). Esta mujer es poseída por diferentes "voces" de la historia nacional desde las más nefastas y atroces (como las voces de Videla y Galtieri) a los ecos fundacionales de la patria con citas de José de San Martín, pasando por Eva Perón, Juan Domingo Perón, Raúl Alfonsín, Carlos Saúl Menem, Estela Carloto, René Favaloro y por voces que pueblan la proyección continental, como el caso del Che Guevara. Uso voice over y voice-off siguiendo la propuesta de Doane y la distinción que sugiere entre ambos, donde el voice over está asociado a la voz sin referente corporal o diegético dentro del filme (como en el documental), y el voice-off asociado a la voz que remite a un personaje que está afuera del marco visual y que por lo tanto está conectado a la historia narrada ("The Voice" 37-43). El problema inicial que plantea "La voz" es establecer cuál es esa historia narrada, puesto que en el comienzo vemos a una mujer cantar el himno nacional y a ella misma con diferentes vestidos y peinados representar a diferentes mujeres argentinas con sus historias.

Por lo tanto, al escuchar la primera voz que se apropia del cuerpo (la de Videla) que está fuera de la diégesis (aunque sólo en parte, porque pertenece a la Historia representada), se produce una irrupción, con lo cual el corto parece poner en escena justamente la dificultad de narrar memorias voluntariamente (es decir de hacer un ejercicio de memoria) al ser interrumpida con otras voces. Esa irrupción, como las memorias involuntarias a las que se refiere Walter Benjamin, transforman el sentido de lo que viene a continuación: una serie de irrupciones de voces que ponen en crisis la memoria como ejercicio deliberado para superponer escenarios diferentes invocados por la sucesión de voces pero que además dificultan la reconstrucción histórica y lineal del pasado. En "La voz", el registro acústico está asociado a la corporalidad (la actriz canta el himno nacional, y además cuenta en primera persona la historia de

Revista Iberoamericana, Vol. LXXXI, Núm. 251, Abril-Junio 2015, 409-433 ISSN 0034-9631 (Impreso)

ISSN 2154-4794 (Electrónico) 


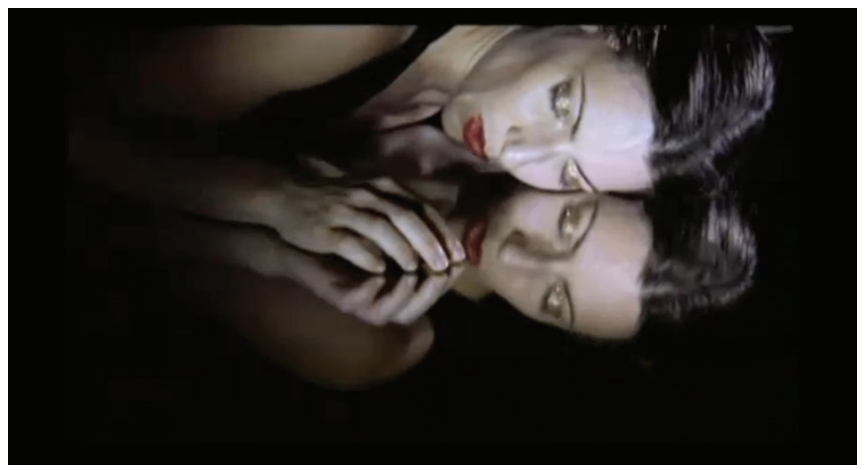

diferentes "personajes": la inmigrante, la nieta de una inmigrante, la compañera de un desaparecido, todas con algo en común: "Yo nací en una época violenta"). A partir de la mención de la desaparición el personaje es poseído por la voz de Videla ("es una incógnita el desaparecido [...] Mientras sea un desaparecido no puede tener ningún tratamiento especial, es una incógnita. Es un desaparecido. No tiene entidad. No está"). La desincronización imagen-voz superpone a la imagen de la mujer (como alegoría de la patria) voces tan disonantes que irrumpen en el canto del himno y en la actuación anterior que habían comenzado a narrar historias de mujeres argentinas. A través de un voice-off que deviene, simultáneamente, voice-over, se usa, por una parte, la voz como voz narrativa. Aunque la actriz gesticula en sincronía con una voz ajena a ella (como en el voice-off) da la clave interpretativa de varios momentos históricos (como en el voice over). Al mismo tiempo, al tratarse de personajes conocidos (como el jefe de la primera junta militar, Eva Perón, Estela Carloto, Juan Domingo Perón, etc.) la voz habita la historia del espectador y no es externa a la historia narrada en el corto. Pero esto se produce justamente por una irrupción de esas voces (y las imágenes virtuales que dispara) en la imagen del corto, produciendo a través de esta simultaneidad entre imagen visual e imagen virtual una imagen que cristaliza el pasado y el presente simultáneamente, es decir una "imagen-cristal". ${ }^{13}$

La patria en presente y sobre todo el canto y recitado del himno están habitados por estas otras voces, que nos dejan saber lo que queda fuera del marco visual, pero que está presente en la narración, desde lo acústico. La narración se aleja de lo histórico, en principio porque las voces no aparecen cronológicamente sino que, se enfatiza el pasado

13 La "imagen-cristal" en Deleuze implica el colapso del tiempo. Para Bergson el tiempo (entendido como duración, es decir entendido como una continuidad sin divisiones) implica una coexistencia del pasado y el presente, Deleuze explica la imagen cristal de esta forma: "Time has to split at the same time as it sets itself or unrolls itself. It splits into two dissymetrical jets, one of which makes all the present pass on, while the other preserves all the past. Time consists of this split, and it is this, it is time, that we see in the crystal" (81).

\footnotetext{
Revista Iberoamericana, Vol. LXXXI, Núm. 251, Abril-Junio $2015,409-433$ 


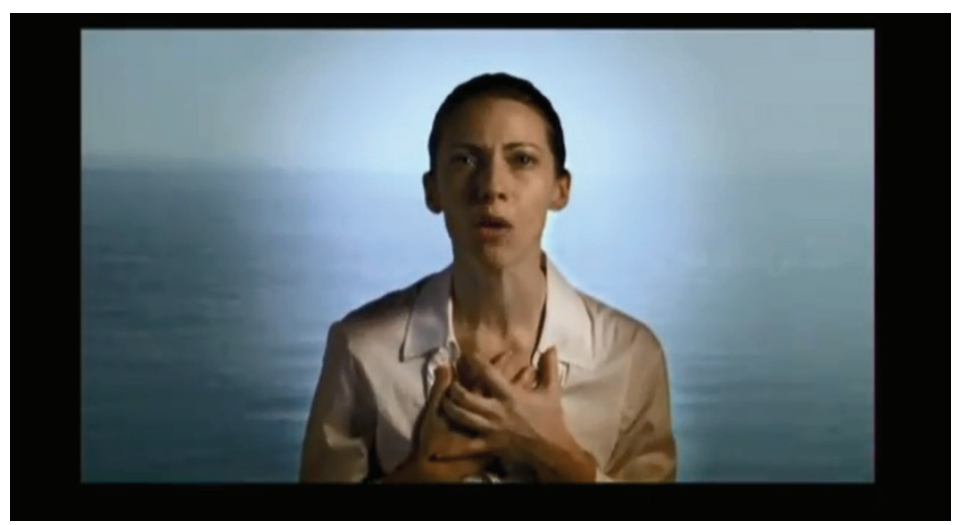

como memoria que deviene presente (y más aun como un caleidoscopio de imágenes sugeridas por las voces). A través de diversas confrontaciones imagen y sonido, el corto atraviesa la historia nacional con interrupciones y pasajes de voz a voz que se dan a veces como una continuidad y que son otras veces abruptos y juegan con la sintonía del sonido de la radio o la televisión y sus interferencias y marcan a través de sonidos muy molestos las irrupciones que producen algunas voces en otras, las rupturas o también las continuidades.

Para Silverman, las posibilidades de trasgresión de la de-sincronización sonidocuerpo se entrelazan con la des-corporización de la voz para que esa voz pueda ser re-situada (en off) y resignificada como trascendente. En este caso, la voz de la nación está corporizada en la mujer que alegoriza la patria con el canto del himno (y de las otras mujeres que ella misma representa y que cuentan su historia, como en una entrevista). Las voces trascendentes (en off/over) son voces asociadas, de forma divergente y muchas veces disonante (expresado más claramente en el momento en que aparece la voz del ex presidente Carlos Saúl Menem) con la vida pública nacional. Sin embargo, las instancias de la voz en este corto, ligadas al recitado y la entonación del himno nacional y a fragmentos que rememoran la marca testimonial de la memoria (en voces en primera persona) se expresan a través de la corporalidad que no sólo repite el texto (o las interferencias de otras voces) sino que se manifiesta (a la manera de un médium) a través de las convulsiones del cuerpo al modularlas. Hacia el final, diferentes imágenes de la actriz en sus diversos roles se suceden mientras se escucha la voz de Juan Domingo Perón, ahora sin que el personaje sea su médium. Del mismo modo, la voz de Estela Carlotto aparece tanto corporalizada en la actriz como escuchada por ésta con imágenes que muestran a quien canta el himno ahora en silencio (pero como sujeto de la escucha), consternada, al oír la voz de las madres y abuelas. El final, con el canto del himno, y la transformación del "juremos con gloria morir" por "juremos con gloria vivir", con la imagen del río, el corto nos remite a la relación que se establece en

Revista Iberoamericana, Vol. LXXXI, Núm. 251, Abril-Junio 2015, 409-433 ISSN 0034-9631 (Impreso)

ISSN 2154-4794 (Electrónico) 
cuanto al espacio, corporeizado a través de la voces asociadas al cuerpo de una mujer (que representa a muchas) y al mismo tiempo, desasociado del cuerpo para señalar otros espacios y tiempos de la patria fuera de la imagen alegórica y que concluye en la imagen de un río como final del recorrido. "La Voz" da cuenta de las posibilidades de representación, no del proceso histórico (y político) de 1810, sino de las irrupciones de la memoria en el intento de revisitarlo.

Aunque podría pensarse, dentro del marco de las discusiones de la memoria, que se trata de una actualización del pasado, de un trabajo de memoria que intenta acomodar el pasado en el presente (como propone en su acercamiento a la memoria Hugo Vezzetti), es posible pensar el trabajo de la temporalidad, tanto en 'La voz' como en los otros cortos discutidos en este ensayo, a partir de la simultaneidad de los tiempos (pasado y presente). La simultaneidad implica también otro acercamiento al espacio, donde el retorno que planteaba anteriormente, a la manera de Benjamin, puede pensarse también como la metáfora espacial que propone Pilar Calveiro al considerar el trabajo de la memoria como un trabajo con las imágenes y las voces. Calveiro propone reemplazar el modelo del puzzle (asociado a los "hallazgos de la memoria", donde cada pieza tiene solo un lugar") por el del caleidoscopio, que reconoce distintas figuras posibles y permite la coexistencia, en vez de la supresión, de voces discordantes" (14). El caleidoscopio, como ese mundo visible, pero fragmentado y habitado de partes nunca fijas, es una imagen que puede condensar las posibilidades de representación de fragmentos que no reclaman totalidad.

La celebración del Bicentenario ofrece el "marco de la memoria" para repensar no sólo el pasado sino el mismo presente, en la medida en que apuntan a la reflexión y a la construcción de una memoria colectiva que perpetúa los sentimientos y las imágenes que están ancladas en la identidad del grupo social, y al mismo tiempo, a la reconstrucción creativa (visual y acústica) del pasado histórico a través de marcos (y encuadres) que sirven para darle sentido a los recuerdos, y fijarlos, de alguna forma. ${ }^{14}$ Es la memoria, las huellas, las cenizas, y sobre todo las borraduras las que se revelan, se traducen en imágenes que ostentan no sólo su potencial capacidad de mostración sino además de condensación poética.

La propuesta representada por los cortos discutidos, desde un llamado oficial de rememoración histórica, implica un pasaje de la mirada por los tiempos de la memoria,

14 Pienso aquí en los marcos según el clásico aporte de Maurice Halbwachs, que retoma Elizabeth Jelin en su propio acercamiento. La idea de los marcos de la memoria enfatiza el presente desde el cual/en el cual el pasado encuentra un lugar a través justamente de la selección que desde el presente le da sentido (colectivamente) a los recuerdos del pasado y habla más del presente que del pasado. De alguna forma en la memoria colectiva se expresa la creatividad del grupo social pero no para hablar del pasado sino del presente, puesto que para Halbwachs lo que no encuentra su lugar en la significación del presente es olvidado.

Revista Iberoamericana, Vol. LXXXI, Núm. 251, Abril-Junio 2015, 409-433 
entendidos como imagen-cristal (y no como el flashback que implica la vuelta a un pasado histórico que se reconoce distintivamente como pasado) sino a una imagen que con-funde los tiempos, desde la simultaneidad y la intermitencia, como puede verse especialmente a través del trabajo voz-imagen que apunta al énfasis no sólo en la imagen que condensa la coexistencia de los tiempos sino además a los diferentes espacios en que se representan paralelamente en esos tiempos (el espacio del espectador, habitado por los sonidos que se emiten sin anclaje en la corporalidad de la imagen, el espacio representado por la imagen, los espacios representados por lo que queda fuera del marco de la imagen pero todavía puede oírse). Volver a mirar los doscientos años del bicentenario resulta así en un ejercicio del recuerdo, un cuestionamiento de los archivos, de las voces de autoridad que narran "objetivamente" los eventos del pasado. Al mismo tiempo este cuestionamiento se produce a través de un énfasis en la memoria (como proceso y como ejercicio) que colapsa de la temporalidad en imágenes que hablan simultáneamente del pasado y del presente, el tiempo se vuelve un intervalo cruzado por los protagonistas, del pasado al presente, produciendo casi un efecto de dejá-vú.

En este sentido, es el retorno al detalle lo que para Benjamin sirve de escenario al trabajo de memoria, pero además permite dar cuenta de lo tardío como un aspecto central de ese trabajo de memoria. Ese retorno de lo tardío está implícito en la imagen de la excavación que también Benjamin usa para referirse al trabajo de la memoria y las diferentes capas que albergan las imágenes del recuerdo (y que están imbricadas también con la historia argentina reciente). La comparación con la tierra en la cual se entierra lo pasado le sirve a Benjamin de punto de partida para usar la metáfora de la excavación en relación con la búsqueda del pasado "enterrado". Benjamin enfatiza la importancia de dar cuenta no sólo de "lo encontrado" sino del proceso mismo de la memoria y de los sujetos del recuerdo, así como de las imágenes que aparecen en el proceso, pero desprovistas del sentido que tenían en el pasado, es decir imágenes que dan cuenta de una pérdida, aunque al mismo tiempo son ubicadas en un nuevo espacio diseñado por visiones del presente. ${ }^{15}$ Las capas atravesadas cuentan tanto como lo hallado para hablar de la memoria, no sólo el lugar del hallazgo, sino además los múltiples espacios que se atravesaron sin encontrar nada, pero que también forman parte de la búsqueda (Part 2, 576). Los cortos de Farji, Martel, Gugliotta, Carri y de Luque en 25 miradas/200 minutos proponen retornos que apuntan si no a crear un nuevo significado al menos a re-ver (volver a mirar) el tiempo pasado y el presente, como una excavación de las imágenes, los sujetos de esas visiones y revisiones y los silencios y los sonidos, como registros acústicos ausentes de los archivos históricos y que son los que permiten envolvernos como espectadores en el espacio que nos rodea para señalar lo que queda

15 Esa relación pasado y presente, entendida también a través de las capas del palimpsesto es una parte central del argumento de Andreas Huyssen en Present Pasts.

Revista Iberoamericana, Vol. LXXXI, Núm. 251, Abril-Junio 2015, 409-433 ISSN 0034-9631 (Impreso)

ISSN 2154-4794 (Electrónico) 
fuera del marco visual y que permite no sólo entender sino además convulsionar los sentidos de los eventos (o las huellas, los ecos y los residuos) que los mismos cortos vienen a representar.

BiBLIOGRAFÍA

25 miradas-200 minutos: los cortos del Bicentenario. Secretaria de cultura de la nación/ Universidad de Tres de Febrero, 2010.

Amado, Ana. "No son como nosotros. Lenguas aborígenes, género y memoria en el cine argentino". International Symposium Erasures: Gender Violence and Human Rights, University of Minnesota. 24-25 oct. 2013.

La imagenjusta: cine argentinoypolítica 1980-2007. BuenosAires: Colihue, 2009.

Benjamin, Walter. Selected Writings. Volume 2, 1927-1934. Michael W. Jennings y Marcus Bullock, eds. Cambridge: Belknap Press of Harvard UP, 1999.

La obra de arte en la época de la reproductibilidad técnica. Buenos Aires: Ediciones Godot, 2012.

Calveiro, Pilar. Política y/o violencia: una aproximación a la guerrilla de los años 70. Buenos Aires: Grupo Editorial Norma, 2005.

Carri, Albertina, dir. "Restos". 25 miradas-200 minutos: los cortos del Bicentenario.

Secretaria de cultura de la nación/ Universidad de Tres de Febrero, 2010.

Caruth, Cathy. Unclaimed Experience: Trauma, Narrative, and History. Baltimore and London: The Johns Hopkins UP, 1996.

Deleuze, Gilles. Cinema 2. Minneapolis: U of Minnesota P, 1989.

De Luque, Paula. "Leyenda del Ceibo". 25 miradas-200 minutos: los cortos del

Bicentenario. Secretaria de cultura de la nación/Universidad de Tres de Febrero, 2010.

Doane, Mary Ann. "The Close-up: Scale and Detail in the Cinema". Differences: A Journal of Feminist Cultural Studies 14/3 (2003): 89-111.

"The Voice in the Cinema: The Articulation of Body and Space." Yale French Studies 60 (1980): 33-50.

Farji, Sabrina, dir. "La Voz". 25 miradas-200 minutos: los cortos del Bicentenario.

Secretaria de cultura de la nación/ Universidad de Tres de Febrero, 2010.

Favio, Leonardo, dir. "Gente querible". 25 miradas-200 minutos: los cortos del

Bicentenario. Secretaria de cultura de la nación/Universidad de Tres deFebrero, 2010. Gugliotta, Sandra, dir. "Posadas". 25 miradas-200 minutos: los cortos del Bicentenario.

Secretaria de cultura de la nación/ Universidad de Tres de Febrero, 2010.

Halbwachs, Maurice. On Collective Memory. Nueva York: Harper and Row, 1980.

Huyssen, Andreas. Present Pasts: Urban Palimpsests and the Politics of Memory.

Stanford: Stanford UP, 2003.

Jelin, Elizabeth. State Repression and the Labors of Memory. Minneapolis: U of Minnesota P, 2003.

Revista Iberoamericana, Vol. LXXXI, Núm. 251, Abril-Junio 2015, 409-433 ISSN 0034-9631 (Impreso)

ISSN 2154-4794 (Electrónico) 
LaCapra, Dominick. Writing History, Writing Trauma. Baltimore: The Johns Hopkins UP, 2001.

Martel, Lucrecia, dir. "Nueva Argiropolis". 25 miradas-200 minutos: los cortos del Bicentenario. Secretaría de cultura de la nación/ Universidad de Tres de Febrero, 2010.

Ranzani, Oscar. "Un mapa de la diversidad de las imágenes." Página/12. 17 junio 2010. $<$ www.pagina12.com.ar/diario/suplementos/espectaculos/5-18333-2010-06-17. html>. 15 junio 2015.

Sarmiento, Domingo F. Argiropolis. Rio de Janeiro, Buenos Aires: Editorial Tor, 1938.

Scarry, Elaine. The Body in Pain: The Making and Unmaking of the World. Nueva York: Oxford UP, 1985.

Silverman, Kaja. The Acoustic Mirror: The Female Voice in Psychoanalysis and Cinema. Bloomington: Indiana UP, 1988.

Vezzetti, Hugo. Pasado y Presente: guerra, dictadura y sociedad en la Argentina. Buenos Aires: Siglo XXI, 2002. 
